\title{
Diurnal chemistry of two contrasting stream types, Taylor Valley, McMurdo Dry Valley Region, Antarctica
}

\author{
Russell S. Harmon ${ }^{1, *}$, Deborah L. Leslie ${ }^{2}$, W. Berry Lyons ${ }^{3}$, Kathleen A. Welch ${ }^{3}$, and Diane M. McKnight ${ }^{4}$ \\ ${ }^{1}$ Department of Marine, Earth, \& Atmospheric Sciences, North Carolina State University, Raleigh, NC 27695, USA \\ ${ }^{2}$ Department of Physical Sciences, Arkansas Tech University, Russellville, AR 72801, USA \\ ${ }^{3}$ School of Earth Sciences, \& Byrd Polar and Climate Research Center, Ohio State University, Columbus 43210, USA \\ ${ }^{4}$ Institute of Arctic and Alpine Research, University of Colorado, Boulder, CO 80309, USA
}

\begin{abstract}
Numerous ephemeral streams flow within the McMurdo Dry Valley Region of Antarctica that transport glacial meltwater to perennially ice-covered, closed-basin lakes during the austral summer. The diurnal behavior for two Taylor Valley streams of different character was examined during the summer of 2010-11. Andersen Creek is a short, 1st-order proglacial stream, whereas Von Guerard Stream is a long, highorder stream with an extensive hyporheic zone that has a substantial cyanobacterial algal mat community in its middle reaches. Both streams display strong daily cycles for temperature, electrical conductivity, dissolved oxygen, and $\mathrm{pH}$. Conductivity varies in concert with flow, with solute dilution occurring during the daily highflow pulse. Dissolved oxygen co-varies strongly with $\mathrm{pH}$ at Andersen Creek but not for Von Guerard Stream. Each stream has a distinct geochemical character that for Andersen Creek is a direct reflection of its glacial source, unmodified by secondary effects, whereas that for Von Guerard Stream is modulated by its resident algal mat community and through extensive hyporheic zone interaction and exchange.
\end{abstract}

\section{Introduction and background}

Located in the central Transantarctic Mountains between the East Antarctic Ice Sheet and the Ross Sea coast of Victoria Land in Antarctica (Fig. 1A), the McMurdo Dry Valley region (MDVR) is the largest ice-free area of Antarctica. The MDVR comprises a set of E-W trending valleys, each about 80 $\mathrm{km}$ long and up to $15 \mathrm{~km}$ wide. In 1993, the U.S. National Science Foundation established Taylor Valley, centered on $77.7^{\circ} \mathrm{S}$ latitude and $162.6^{\circ} \mathrm{E}$ longitude in the central MDVR (Fig. 1B), as a Long-Term Ecological Research site that aims to understand the physical and biological processes operating within this polar desert ecosystem. The landscape across the MDVR is a mosaic of Paleozoic-Mesozoic igneous and sedimentary bedrock, glaciers, closedbasin lakes, and open expanses of barren

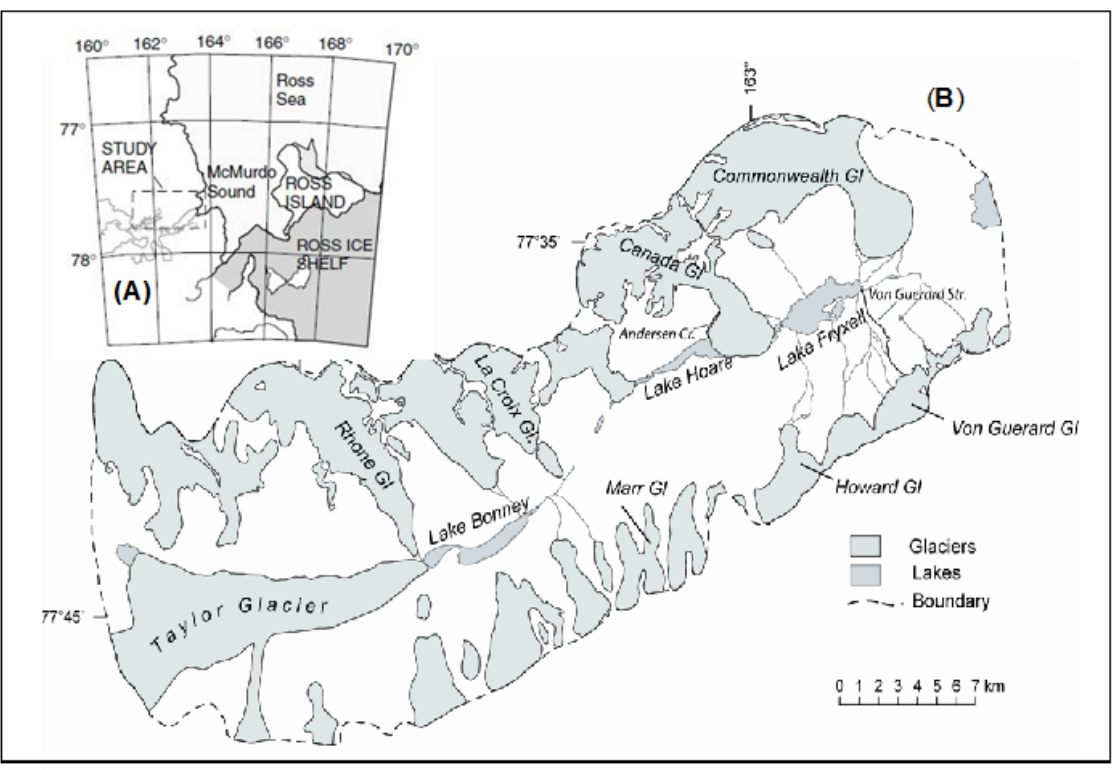

Fig. 1. Location maps, McMurdo Dry Valleys Region, Antarctica.

patterned ground covered by gravelly-sandy alluvial soils [1]. Numerous ephemeral streams flow within Taylor Valley each year during the austral summer, where they transport glacial meltwater to three perennially ice-covered closed-basin lakes Lake Bonney, Lake Hoare, and Lake Fryxell. This investigation of stream geochemistry was undertaken during the austral

*Corresponding author: rsharmon@ncsu.edu 
summer of 2010-11 to investigate diurnal fluctuations at two Taylor Valley streams and gain insight into their compositional controls.

Hydrologic activity in the MDVR is a consequence of glacial melting during the austral summer which creates ephemeral streams that flow to closed basin lakes for between 6-12 weeks each year [2]. Within Taylor Valley, these streams are short, having lengths that range from 1 to $11 \mathrm{~km}$. The MDVR landscape is underlain by thick permafrost [3] that precludes a deep groundwater contribution to streamflow, but its surficial melting each summer season creates an active zone that permits movement of fluid to about a meter's depth [4]. Zones of continuous wetness are produced in the highly permeable surface alluvium by water seeps and stream flow that leads to the development of hyporheic zones within the active layer around stream channels [2]. These important hydrologic elements can extend several meters from the edge of larger streams, as water moves into the soil and gets wicked away from the stream edge due to capillary suction [5]. Because glacier surface temperature is typically near the ice melting point during the summer [6], streamflow is quite flashy and exhibits large diurnal variation that is determined for each stream by the orientation of its source glacier and the solar trajectory. Consequently, streams exhibit different runoff patterns due to local conditions such as wind direction, air temperature, incident solar radiation, snowfall, and glacier topographic character and orientation. Stream flow regimes throughout Taylor Valley are characterized by short and intense peak flow events that can approach $500 \mathrm{~L} / \mathrm{s}$ [7] and most streams can experience several days of no flow during the summer [8]. Stream chemistry across Taylor Valley is surprisingly diverse, in general characterized by $\mathrm{Alk}>\mathrm{Cl}>\mathrm{SO}_{4}$ and either $\mathrm{Ca}>\mathrm{Na}>\mathrm{Mg}>\mathrm{K}$ or $\mathrm{Na}>\mathrm{Ca}>\mathrm{Mg}>\mathrm{K}$ [9]. Streams in Taylor Valley can be divided into two groups based on physical character - short streams $(<2 \mathrm{~km})$ with small, steep, rocky and regularly-scoured channels that have hyporheic zones of minimal extent surrounding their channels and longer streams $(>2 \mathrm{~km}$ ) having substantial low-gradient reaches characterized by well-developed hyporheic zones and channels that contain benthic cyanobacterial algal mats in stable sections that reactivate and grow slowly during periods of summer flow [2]. Thus, stream length provides a framework for comparing streams across Taylor Valley and it is this framework utilized in this study.

\section{Andersen Creek and Von Guerard Stream}

Andersen Creek (AC) is a first-order proglacial meltwater stream located in the Lake Hoare basin that drains the western sector of the Canada Glacier (Fig. 1B). AC flows southwestward for $1.4 \mathrm{~km}$ along the foot of the glacier, where it is not exposed to direct sunlight, into the west end Lake Hoare. Throughout almost all of its length, AC runs over a steep rocky bed in a narrow and shallow channel that is devoid of algal material. The stream moves away from the base of the glacier in its distal reaches and flows across a flat sandy deltaic area before discharging into Lake Hoare. Because of this setting, hyporheic zone development around AC is minimal and a previous study indicates little to no hyporheic zone influence on stream chemistry at AC [10]. Like other Taylor Valley glaciers, Canada Glacier contains cryoconite melt holes within the surface ice of the ablation zone that contain accumulations of wind-transported aerosols and sediment together with a diverse biotic community [11]. Biogeochemical processes with cryoconite holes on Canada Glacier are thought to directly influence the chemistry of meltwater input to AC through the interconnectedness of the glacier's internal hydrologic network [12].

Von Guerard Stream (VGS) is located on the southeastern side of the Fryxell basin where it drains the Von Guerard Glacier and flows northwestward into the east end of Lake Fryxell (Fig. 1B). Unlike AC with its simple and largely constant source to outlet hydrologic character, VGS comprises a complex stream network that changes significantly in physical and ecological character during its $5.6 \mathrm{~km}$ course [13]. Stream flow begins in three small channels that coalesce into a 5-8 $\mathrm{m}$ deep channel of steep gradient cut into glacial till and, after that, combined stream flow is on a bed of unconsolidated sandsized alluvium that contains boulders and cobbles. It changes in its middle reach, after flowing across gently sloped sandy section, to a long segment of moderate gradient stream that flows in a wide 3-6 m deep channel within a stabilized stone pavement before again flattening out into a largely sandy stream channel in its lower reaches. VGS is exposed to direct solar radiation throughout its course. The intermediate reach of the stream contains abundant benthic algal mats and the stream has a well-developed hyporheic zone throughout its low-gradient reaches. Together, continuous interaction between stream and soil along the channel margins and chemical weathering in the more distal portions of the wetted domain act in concert to both regulate biogeochemical processes and modulate stream temperature and chemistry [13-15].

\section{Results and discussion}

Time-series sampling at 5-minute intervals was undertaken at VGS for 4215 minutes from 1700 on 31 December 2010 to 1520 on 3 January 2011 and then at AC for 5600 minutes from 1700 on 3 January to 1415 on 7 January 2011 during the summer period of main stream flow when glacial melting is maximal and stream hyporheic zones are fully developed. Streams were monitored at locations in their downstream reaches close to flow monitoring gages situated upstream of respective lake entrances. Water temperature $(\mathrm{T})$, total dissolved solids content measured as electrical conductance (SPC), 
dissolved oxygen (DO), and pH were determined in situ using a Yellow Springs Instrument multi-parameter probe. Samples for chemical analysis were collected at 4-hr intervals over the course of this diel study as described by Lyons et al. [16].

Discharge hydrographs for each stream are shown in Figure 2A. Over the course of the 2010-11 summer, the local high streamflow interval occurred at $\sim 1730$ for the southeast-facing AC and some four hours later at $\sim 2130$ for the northwestfacing VGS [17], reflecting glacier orientation and solar trajectory control on melting for the two source glaciers. Respective discharges during the sampling intervals ranged from 0.5 to $68 \mathrm{~L} / \mathrm{sec}$ for AC compared to 1.3 to $185 \mathrm{~L} / \mathrm{sec}$ for VGS. Both hydrographs are flashy, governed by the diurnal cycle of glacial melting and refreezing, rising sharply for both streams with the onset time of daily melting, but sustained longer at high flow for VGS than for AC which displayed significant short time scale variation. Ranges of T, SPC, DO, and $\mathrm{pH}$ were: $\mathrm{T}=-0.7$ to $2.9^{\circ} \mathrm{C}, \mathrm{SPC}=36$ to $146 \mu \mathrm{S} / \mathrm{cm}, \mathrm{DO}$ $=5.8$ to $11.3 \mathrm{mg} / \mathrm{L}\left(67-99 \%\right.$ saturation), and $\mathrm{pH}=6.0$ to 7.9 for $\mathrm{AC}$ compared with $\mathrm{T}=0.6$ to $10.6{ }^{\circ} \mathrm{C}, \mathrm{SPC}=80$ to 131 , $\mu \mathrm{S} / \mathrm{cm}, \mathrm{DO}=5.5$ to $9.6 \mathrm{mg} / \mathrm{L}$ (86-99\% saturation), and $\mathrm{pH}=5.6$ to 8.3 for VGS. Both streams exhibit well-defined diurnal cycles for these four parameters, with episodes of stream baseflow characterized by high dissolved solute load, high $\mathrm{pH}$, and low DO content. As expected, times of elevated DO content correspond to daily episodes of glacial melting when streams are well oxygenated because of high, turbulent flow. Both streams exhibit low, near-freezing temperatures in the early morning, but then display distinct temperature characteristics during the remainder of their diel cycle. Temperature at AC remained below $3{ }^{\circ} \mathrm{C}$ throughout the diurnal interval and the daily temperature variation is uncorrelated with discharge. By contrast, VGS reached a high temperature of around $10^{\circ} \mathrm{C}$ in the mid-late afternoon, during the lowest flow interval of the daily cycle that immediately preceded the daily high-flow pulse, when it decreased sharply. Figure 2B displays a similar SPC-flow relationship for both streams that records the dilution of solute loads during the daily high flow pulse generated by glacial melting. Although both streams reach somewhat similar elevated maximum solute loads $\left(\mathrm{SPC}_{\max }=146 \mu \mathrm{S} / \mathrm{cm}\right.$ for $\mathrm{AC}$ versus $\mathrm{SPC}_{\max }=131 \mu \mathrm{S} / \mathrm{cm}$ for VGS), their daily minima are distinctly different. The lowest conductivity recorded for VGS was more than double that for $\mathrm{AC}\left(\mathrm{SPC}_{\min }=36 \mu \mathrm{S} / \mathrm{cm}\right.$ for $\mathrm{AC}$ versus $\mathrm{SPC}_{\min }=80 \mu \mathrm{S} / \mathrm{cm}$ for VGS), with the individual conductivity-flow relationships implying different controls on stream chemistry during the daily flow cycle. It is notable that conductivity correlates strongly with flow volume at $\mathrm{AC}\left(\mathrm{R}^{2}=0.80\right)$ but much less so at the VGS $\left(\mathrm{R}^{2}=0.37\right)$.

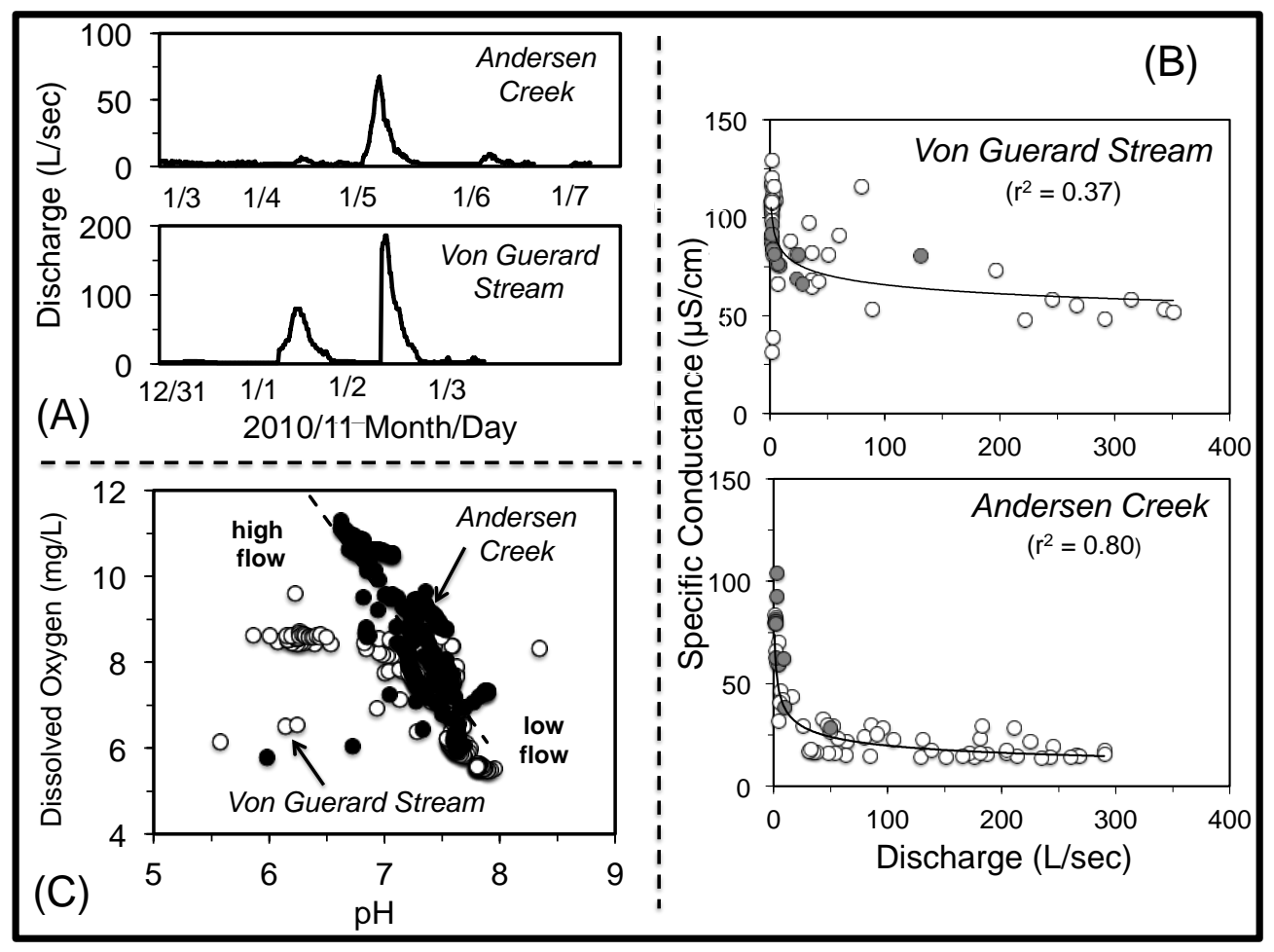

Fig. 2. A - Discharge hydrograph for AC (top) and VGS (bottom) over the intervals of diurnal monitoring; B - Specific conductivity versus flow volume (shaded symbols $=$ diurnal sampling intervals, open symbols $=2010-11$ austral summer season from $12 / 8 / 10$ to 1/20/11); C- Dissolved oxygen versus pH for the diurnal sampling intervals (filled symbols $=$ AC, open symbols $=$ VGS).

Notably, each stream has a specific geochemical fingerprint: $\mathrm{Alk}>\mathrm{Ca}>\mathrm{Cl}>\mathrm{Na}>\mathrm{SO}_{4}>\mathrm{Mg}>\mathrm{K}>\mathrm{Si}$ for $\mathrm{AC}$ and $\mathrm{Alk}>\mathrm{Ca}>\mathrm{Na}>\mathrm{Cl}>\mathrm{Si}>\mathrm{Mg}>\mathrm{K}>\mathrm{SO}_{4}$ for VGS, patterns that also characterize the historic compositional record for these two streams. A study of meltwater sources from the Canada Glacier documented that $\mathrm{Ca}>\mathrm{Cl}>\mathrm{Na}>\mathrm{SO}_{4}>\mathrm{Mg}$ for supraglacial streams but that $\mathrm{Ca}>\mathrm{Cl}>\mathrm{SO}_{4}$ for cryoconite hole waters [12]. This observation readily explains the difference in stream chemistry and compositional variability between the two streams. The extensive hyporheic zone at VGS, which is a domain 
of biogeochemical activity and water-sediment interaction through ion exchange and mineral dissolution that acts to both elevate and buffer its overall solute content as well as enrich stream water in alkalinity, $\mathrm{Ca}$, and $\mathrm{Si}$ via acid neutralization during chemical weathering of either silicate or carbonate minerals (e.g. $\mathrm{NaAlSi}_{3} \mathrm{O}_{8}+4 \mathrm{H}^{+}+4 \mathrm{H}_{2} \mathrm{O} \Leftrightarrow \mathrm{Na}^{+}+\mathrm{Al}^{3+}+3 \mathrm{H}_{4} \mathrm{SiO}_{4}$ and $\mathrm{CaCO}_{3}+\mathrm{H}_{2} \mathrm{CO}_{3} \Leftrightarrow \mathrm{Ca}^{+}+2 \mathrm{HCO}_{3}^{-}$) to produce its geochemical fingerprint of $\mathrm{Alk}>\mathrm{Ca}>\mathrm{Na}>\mathrm{Cl}>\mathrm{Si}>\mathrm{Mg}>\mathrm{K}>\mathrm{SO}_{4}[9,13$, $18,19]$. By contrast, flow in the proglacial AC is largely derived from a combination of low solute and Si-depleted glacial meltwater and supraglacial stream water [20] plus cryoconite hole water enriched in $\mathrm{Cl}$ and $\mathrm{SO}_{4}$ through the dissolution of both glacial surface dust accumulations and seasalt contained in glacier ice as cryoconite hole development proceeds [21]. Thus, the chemistry of $\mathrm{AC}$, with its minimal hyporheic zone, more closely reflects the composition and high variability of its glacial source waters and displays the long-term geochemical fingerprint $\mathrm{Alk}>\mathrm{Ca}>\mathrm{Cl}>\mathrm{Na}>\mathrm{SO} \mathrm{O}_{4}>\mathrm{Mg}>\mathrm{K}>\mathrm{Si}$ [9] that is biased towards $\mathrm{Cl}$ and $\mathrm{SO}_{4}$, such that $\mathrm{Cl}$ can even be elevated over $\mathrm{Ca}$ during high-flow intervals. As the daily glacial melt diminishes and stream discharge at $\mathrm{AC}$ returns to its low flow condition, water with elevated conductivity from cyroconite holes dominates the solute budget and is largely unmodified during its short surface channel flow. These contributions from waters having resided in cryoconite holes on the Canada Glacier are temporally, spatially, and compositionally variable. Such cryoconite holes can exist for up to a decade and create a near-surface hydrologic system extending tens of centimeters below the glacier ice surface, with some half of the holes isolated and the other half connected to the near-surface hydrologic system [11]. Separate holes have been observed to exhibit independent cycles of water storage and release to the larger internal glacier hydrologic network and have been determined to contribute at least $13 \%$ of the observed glacial melt runoff [11]. This baseflow signal is then diluted at times of higher discharge when water derived from supraglacial streams and melting glacier ice with SPC values $<20[12,20]$ dominates the flow. The small solute fluctuations observed at higher discharges are attributed to differential partitioning of water within internal glacier hydrological network and its compositional variability over time.

VGS displays a similar concentration-flow behavior to AC, but with more variability. As flow here diminishes towards its daily minimum, it is warmed by solar radiation and then moves into the hyporheic zone along preferential flow paths, raising its temperature ahead of the daily meltwater pulse [15]. The relative compositional consistency of VGS over the entirety of a summer flow season reflects compositional modulation by its extensive mid-reach hyporheic zone, where water in transient storage introduced during times of high stream flow has an extended opportunity for water-sediment interaction and pore-water exchange before a portion returns to the main stream channel during the daily low-flow interval. Our observations, together with the compositional distinction that characterizes the two streams, support the idea of a 2-part hyporheic zone for larger Taylor Valley streams [22] in which a well-connected but heterogeneous, thermally-regulated, and highly-interactive hyporheic zone is present around large stream channels that holds water in transient storage within the active zone and exchanges water with the main stream on multiple temporal and spatial scales [23, 24]. In this model, a highly interactive near-stream hyporheic zone, that experiences rapid stream-water exchange on a flow equivalent time scale as water travels from glacier source to lake inflow, is connected to a more distant hyporheic zone that extends to the distal reaches of the wetted zone away from the stream, with the latter characterized by longer flow paths and slower exchange. This hyporheic domain is larger and more complex for longer streams and exerts a more pronounced influence on temperature and composition than for smaller streams [7, 25-27]. The higher minimum conductivity value for VGS compared to AC is interpreted to reflect a steady input of such distal hyporheic zone water to VGS flow. Contributions of this water, with its higher ion concentrations resulting from extensive fluid-sediment interaction [13,14], is greatest during low flow intervals when it buffers the dissolved solute load of the VGS to a higher level than observed at AC where glacial meltwater dominates stream flow. The more variable conductivity-discharge relations observed for VGS over the course of the entire flow season (Fig. 3A) is a reflection of the complex dynamics of hydrologic and hydraulic processes, operating across multiple temporal and spatial scales, that control the hyporheic zone behavior of larger Taylor Valley streams.

High flows at both AC and VGS are dominated by glacial meltwater, with intervals of baseflow at both streams characterized by high levels of total dissolved solids, high $\mathrm{pH}$ values, and low DO contents. As illustrated in Figure 2C, there is a well-expressed negative co-variation of $\mathrm{pH}$ with $\mathrm{DO}$ for $\mathrm{AC}$, such that episodes of low flow are characterized by high $\mathrm{pH}$ and low DO. This situation is interpreted to reflect control by the biological processes within the cryoconite holes complex of the Canada Glacier. Photosynthesis by the diverse community of photoautotrophs within cryoconite holes consumes hydrogen ion $\left(\mathrm{HCO}_{3}{ }^{-}+\mathrm{H}^{+} \Leftrightarrow \mathrm{CH}_{2} \mathrm{O}+\mathrm{O}_{2}\right)$ and generates $\mathrm{CO}_{2}$-depleted waters of elevated $\mathrm{pH}$ and DO [20]. The more alkaline waters produced are then transmitted through the internal glacier drainage network that creates the AC proglacial stream but also degassed during this flow. This effect is most pronounced during intervals of lowest flow when the supraglacial streams that feed the internal hydrological network of the Canada Glacier are in a frozen state so that cryoconite hole contribution to the AC flow budget is maximized. The situation for VGS is more complex because of its algal mat community and extensive hyporheic zone. Benthic mat photosynthesis will consume bicarbonate and generate oxygen, thus elevating $\mathrm{pH}$ and $\mathrm{DO}$, the signature of which will be most pronounced during time of stream baseflow. The particulate organic matter produced through biological activity at VGS [28] is introduced into the near-stream hyporheic zone during transient storage, where it is oxidized before being returned to the main streamflow during later low-flow episodes. 


\section{Summary}

Diurnal variations measured at high temporal resolution provide insight into process controls on stream chemistry in the polar desert of Taylor Valley, Antarctica. At high flow, stream compositions are dominated by low solute glacial meltwater. For AC, streamflow throughout the diurnal cycle directly reflects mixing in variable proportions of different types of Canada Glacier meltwater, i.e. that derived from supraglacial streams, bulk ice melting, and cryoconite holes. Here, solute-enriched alkaline water from cryoconite holes dominates the stream chemical budget during low flow intervals. Once in AC, this proglacial water is largely unmodified during subsequent channel flow to Lake Hoare. By contrast, VGS chemistry is affected during low flow by both the biological activity of benthic algal mat community present in its middle reaches as well return flow from water within its extensive and structurally complex hyporheic zone. As flow in VGS diminishes towards its daily minimum, water equilibrated in the higher temperature portions of the hyporheic zone contributes return flow into the stream channel and raises stream water temperature ahead of the daily high discharge meltwater pulse. The relative compositional consistency of VGS over a summer flow season reflects hyporheic zone regulation, where water in transient storage introduced during times of high stream flow has an extended opportunity for water-sediment interaction, silicate mineral dissolution, and pore-water exchange at multiple spatial and temporal scales before returning to main stream channel during the daily low-flow interval.

This work was supported by NSF grants OPP-ANT-0423595 and OPP-ANT-1637708. We thank the MCM-LTER 'stream team' for collecting the hydrologic monitoring data shown in Figure 2.

\section{References}

1. W.J. Green, M.P. Angle, K.E Chave KE, Geochim. Cosmochim. Acta 52 (1998)

2. D. McKnight, D. Niyogi, A. Alger, A. Bomblies, P. Conovitz, C. Tate, Bioscience, 49 (1999)

3. I. Campbell, G. Claridge, D. Campbell, M. Balks, AGU Ant. Res. Ser., 72 (1998)

4. J. Bockheim, I. Campbell, M. McLeod, Permafrost Periglacial Proc., 18 (2007

5. R. Runkel, D. McKnight, E. Andrews, J. North Amer. Benthic Soc., 17 (1998)

6. M. Hoffman, A. Fountain, G. Liston, J. Geophys. Res., 113 (2008)

7. P. Conovitz, D. McKnight, L. MacDonald, A. Fountain, H. House, 1998, AGU Ant. Res. Series, 72 (1998)

8. P. Von Guerard, D. McKnight, R. Harnish, A. Gartner, A. Andrews, USGS Open File Report 94 (2005)

9. W. Lyons, K. Welch, K. Neumann, J. Toxey, R. McArthur, C. Williams, D. McKnight, D. Moorhead D, AGU Ant. Res. Series 72 (1998)

10. S. Fortner, W. Lyons, L. Munk, 2013. Hydrol. Proc., 27 (2013)

11. A. Fountain, M. Tranter, T. Nylen, K. Lewis, D. Mueller, J. Glaciology 50 (2004)

12. S. Fortner, M. Tranter, A. Fountain, B. Lyons, K. Welch, Aquatic Geochem., 11 (2005)

13. M. Gooseff, D. McKnight, W. Lyons, A. Blum, Water Resour. Res., 38 (2002)

14. D. McKnight, R. Runkel, C. Tate, J. Duff, D. Moorhead , J. North Amer. Benthic Soc., 23 (2004)

15. K. Cozzetto, D. McKnight, T. Nylen, A. Fountain, Adv. Water Resour., 29 (2006)

16. W. Lyons, D. Leslie, R. Harmon, K. Neumann, K. Welch, K. Bisson, D. McKnight, Appl. Geochem. 32 (2013)

17. D. Leslie, K. Welch, W. Lyons, Hydrol. Proc., 31 (2017)

18. P. Maurice, D. McKnight, L. Leff, M. Gooseff, Geochimim. Cosmochim. Acta, 66 (2002)

19. C. Nezat, W. Lyons, K. Welch, Geol. Soc. Amer. Bull., 113 (2001)

20. W. Lyons, K. Welch, A. Fountain, G. Dana, B. Vaughn, D. McKnight, Hydrol. Proc., 17 (2003)

21. M. Tranter, A. Fountain, C. Fritsen, W. Lyons, J. Priscu, P. Statham, K. Welch, Hydrol. Proc., 18 (2004)

22. M. Gooseff, D. McKnight, R. Runkel, B. Vaughn, Hydrol. Proc., 17 (2003)

23. K. Cozzetto, K. Bencala, M. Gooseff, D. McKnight, Water Resour. Res., 49 (2013)

24. J. Singley, A. Wlostowski, A. Bergstrom, E. Sokol, C. Torrens, C. Jaros, C. Wilson, P. Hendrickson, M. Gooseff, Water Resour. Res., 53 (2017)

25. J. Koch, D. McKnight, R. Neupauer, Water Resour. Res., 47 (2011)

26. M. Gooseff, A. Wlostoski, D. McKnight, C. Jaros, Geomorphology 277 (2017)

27. A. Wlostowski, M. Gooseff, D. McKnight, C. Jaros, W. Lyons, Hydrol. Proc., 30 (2016)

28. J. Cullis, L. Stanish, D. McKnight, Water Resour. Res., 50 (2014) 